\title{
REVOLUSI MENTAL MELALUI NILAI MEMAAFKAN
}

Oleh: Yohanes Fransiskus Siku Jata

\section{Abstrak}

A

rtikel ini bertujuan untuk mengangkat sebuah nilai yang perlu dikembangkan dalam pendidikan karakter yakni nilai memaafkan atau mengampuni. Memaafkan dalam konteks yang lebih dalam mesti diusahakan sebagai bagian dari nilai yang ingin dikejar dari revolusi mental. Tetapi memaafkan merupakan nilai yang tidak gampang untuk dikejar. Kesulitan mewujudkan nilai memaafkan karena manusia berada dalam tegangan antara egoisme dan sifat altruistik. Pergumulan teoritis melalui kajian kepustakaan dan fakta sosial tentang praktek memaafkan, memberikan pemahaman bahwa memaafkan merupakan sesuatu yang tidak gampang. Memaafkan menjadi sebuah kebajikan, sebuah nilai yang perlu diperjuangkan terus menerus tanpa mengenal kata berhenti apalagi puas.

Kata Kunci: Menyerang,Penyerang, kata-kata makian, sakit hati, tercela. Memaafkan.

\section{Pendahuluan}

Mengawali tulisan ini, Penulis ingin menyebut tiga kata berikut: l'offensore, l'offesa dan l'offeso. Ini adalah tiga kata bahasa Italia. L'offensore berarti penyerang, yang menyerang, yang menyerbu, yang menghinakan, orang berdosa, pelanggar. L'offesa berarti penghinaan, makian, kata-kata yang keji, kesalahan, dosa, nista, cela. Dan l'offeso berarti sakit hati, merasa sakit hati, merasa hina, ternista, terhina, tercela (Lorenzo Lini, 1982: 421-422).

Yang dimaksudkan dengan l'offensore ialah orang yang oleh karena tindakan atau perbuatannya, dia mendatangkan atau menyebabkan orang lain merasa sakit hati, merasa terhina atau dihinakan. Yang dimaksudkan dengan l'offesa ialah tindakan atau perbuatan penghinaan itu sendiri yang dilakukan oleh l'offensore sehingga membuat orang lain merasa terhina atau dihinakan. Sedangkan, yang dimaksudkan dengan l'offeso ialah orang yang mengalami dan merasakan sakit hati oleh karena tindakan atau perbuatan penghinaan yang dilakukan oleh l'offensore terhadap dirinya. Dia adalah orang yang disakiti, dihinakan, korban dari katakata keji atau tindakan tercela dari sang l'offensore. Pendeknya, l'offensore adalah penghina (pelaku), l'offesa adalah penghinaan, dan l'offeso adalah dia yang dihinakan (korban).

Tiga kata ini adalah elemen-elemen penting jika orang ingin berbicara tentang memaafkan atau memberi maaf. Mengapa? Karena tindakan atau perbuatan memaafkan itu tidak akan ada, kalau seandainya tidak ada penghina atau pengkhianat dan tidak ada orang yang merasa dihinakan (disakiti, dicela). Tindakan memaafkan adalah sebuah tindakan yang datang dari orang atau pribadi yang merasa dirinya disakiti atau dihinakan, dan tertuju kepada orang yang mendatangkan sakit hati bagi dirinya.

Jadi, tindakan memberi maaf adalah tindakan yang datang dari orang yang hatinya disakiti dan dihinakan, serta terarah kepada penghina atau pencipta rasa sakit. Karena penghina atau pelanggar adalah pribadi yang telah melakukan tindakan pengkhianatan terhadap dia yang terhina dan terluka. Situasi ini menunjukkan bahwa tindakan memaafkan atau memberi maaf itu merujuk ke masa lampau, kepada peristiwa atau pengalaman yang telah terjadi, yaitu pelanggaran, penghinaan atau pengkhianatan yang telah dilakukan oleh seseorang terhadap sesamanya. 


\section{Penghina, Penghinaan dan Korban Penghinaan}

Siapa itu penghina atau pengkhianat? Penghina adalah seseorang yang mendatangkan kerugian, kerusakan, cedera, bencana, celaka atau kemalangan pada diri orang lain. Dia adalah orang yang melakukan suatu kejahatan kepada orang lain (Jean Laffitte, 2000: 55). Tindakan kejahatan yang dilakukannya disebut penghinaan atau pengkhianatan, dan dengan tindakannya itu dia telah mendatangkan kerugian, rasa sakit atau penderitaan pada diri orang lain.

Apa itu penghinaan? Penghinaan atau pengkhianatan adalah suatu tindakan dengan mana seseorang secara publik memperlihatkan penghinaannya kepada seseorang (orang lain). Secara umum, penghinaan itu sesungguhnya bersumber dan mengalir dari hasrat atau gerak hati yang penuh dengan amarah (J.L. Brugues, 1994: 258). Karena itu, penghinaan ini sering didefinisikan sebagai suatu "kejahatan moral, perbuatan jahat, pelanggaran yang berat, tindakan atau ekspresi yang mendatangkan kerugian dan merupakan suatu tindakan yang melawan hukum" (N. Zingarelli, 2004: 1202). Setiap kejahatan atau tindakan yang mendatangkan kerugian yang dilakukan oleh penghina atau pengkhianat kepada orang lain adalah suatu penghinaan. Dan seorang pribadi yang dihina, dikhianati, dia adalah seorang yang terhina, seorang yang terluka.

Hubungan antara penghina dengan yang terhina (korban penghinaan) adalah hubungan sebab-akibat. Penghina atau pengkhianat adalah penyebab yang mendatangkan kerugian, cedera, bencana, rasa sakit, penderitaan dan perasaan terluka, karena dia telah melakukan suatu tindakan yang jahat (keburukan). Orang yang dihinakan adalah orang yang terluka oleh karena tindakan penghinaan si penghina. Jadi, akibat dari tindakan penghinaan yang dilakukan oleh penghina atau pengkhianat terhadap si terhina ialah bahwa korban penghinaan menjadi sakit, karena dia terluka.

Setiap penghinaan selalu mendatangkan rasa sakit dan penderitaan dalam diri orang yang dihinakan. Dan penghinaan itu dapat diekspresikan dalam aneka macam bentuk. Ada penghinaan fisik, penghinaan psikologis atau afektif, penghinaan intelektual, penghinaan moral dan penghinaan spiritual (Jean Laffitte, 2000: 38-42).

Penghinaan fisik adalah penghinaan yang biasa dilakukan dengan mencelaki orang lain. Suatu kecelakaan yang direncanakan dan ditetapkan oleh seseorang agar terjadi pada diri orang tertentu, yang sebelumnya orang itu sendiri tidak pernah tahu bahwa dia akan mengalami kecelakaan. Orang yang melakukan penghinaan fisik adalah orang yang mau melukai dan menyakiti hati sesamanya dengan cara mendatangkan kecelakaan fisik pada diri orang yang mau disakiti.

Penghinaan psikologis atau afektif adalah semua aktivitas atau tindakan penghinaan yang bertujuan melukai diri seseorang secara psikologis. Penghinaan ini juga bisa diungkapkan dalam bentuk meninggalkan cap-cap negatif pada diri seseorang yang mau dihinakan. Jadi penghinaan psikologis adalah satu jenis penghinaan yang dilakukan oleh seseorang terhadap orang lain atau juga sekolompok orang dengan maksud mencederai orang yang mau dihinakan.

Penghinaan intelektual biasanya dilakukan dengan cara melumpuhkan hak orang dalam mencari kebenaran. Orang yang mau dihinakan itu dilukai hatinya dengan cara mengatakan sesuatu yang tidak benar tentang dirinya. Penghina atau pengkhianat dapat melakukannya dengan berkata bohong, mengatakan sesuatu yang tidak benar, atau juga bertindak palsu, memanipulasi dengan maksud agar orang yang dihinakan itu tidak berkembang dalam hidupnya.

Penghinaan moral adalah bentuk penghinaan yang dapat dilakukan secara fisik maupun secara psikologis yang bermaksud untuk melumpuhkan hidup seseorang. Penghinaan itu dapat dinyatakan dengan mengatakan hal-hal yang buruk tentang orang lain (yang mau dihinakan), melakukan tekanan dan paksaan serta membuat aksi-aksi yang melahirkan perasaan takut dalam diri orang yang dihinakan. 
Dan penghinaan spiritual adalah jenis penghinaan yang sangat berat, yang menyentuh relasi antara manusia dengan Allah. Penghinaan ini melukai seseorang dalam memenuhi haknya untuk mencapai kebaikan spiritual; juga merupakan penghinaan yang membunuh seseorang dalam usahanya untuk mencapai kebebasan religius.

\section{Memaafkan: Siapa Yang Harus Memulai?}

Memaafkan adalah salah satu tindakan baik yang dilakukan oleh seseorang dalam relasi dengan yang lain.Tindakan memaafkan itu perlu, ketika relasi yang dibangun antara seorang dengan yang lain dirusak oleh penghina (pengkhianat) oleh tindakan penghinaan atau pengkhianatan. Normalnya, aktivitas memaafkan atau memberi maaf datang dari orang yang dihinakan kepada orang yang menghinanya (dari dia yang terhina, terluka, korban penghinaan terhadap penghina atau pengkhianat). Dan tujuan dari tindakan memaafkan itu adalah rekonsialiasi (perbaikan, penghentian permusuhan) antara mereka.

Pertanyaan tentang siapa yang harus berinisiatip untuk memulai tindakan memaafkan adalah pertanyaan yang sangat penting untuk memulai proses memaafkan. Mengapa? Karena sebuah proses, baru akan berjalan, kalau proses itu sudah dimulai. Di sini, memulai mengambil tindakan untuk masuk dalam proses maafmemaafkan menjadi penting dan mendesak. Karena tindakan memaafkan sesungguhnya adalah ujung dari sebuah proses relasi yang dibangun oleh penghina atau pengkhianat dengan dia yang dihinakan atau korban penghinaan (berkenaan dengan tindakan penghinaan yang telah terjadi pada masa lalu). Untuk itu, terhadap pertanyaan: dalam proses maaf-memaafkan, siapa yang harus lebih dahulu mengambil inisiatif, jawabannya adalah penghina atau pengkhianat.

Tindakan pertama yang harus dilakukan oleh penghina adalah menyadari apa yang telah dilakukannya pada masa lampau terhadap orang yang dia hinakan. Di sini, sadar akan apa yang telah dilakukan, sadar akan tindakan yang telah merugikan orang, menjadi penting. Mengapa? Karena jika orang tidak pernah sadar bahwa dia telah melakukan kesalahan atau telah membawa petaka bagi orang lain, maka proses maaf-memaafkan tidak bisa dimulai. Tindakan memaafkan hanya akan berjalan kalau penghina menyadari kesalahan yang telah dilakukannya. Jadi point penting di sini adalah kesadaran penghina akan kesalahannya. Dalam proses ini, penghina atau pengkhianat harus mengevaluasi tindakannya pada masa lalu (Jean Laffitte, 2000: 54). Dan ini sesungguhnya adalah hal yang fundamental.

Sebuah proses tidak akan bisa berjalan, kalau seandainya tidak ada orang yang ingin memulai. Dalam kasus ini, titik berangkat harus dimulai dari diri penghina atau orang yang telah mendatangkan rasa sakit dan terluka pada orang lain. Dengan demikian, pertanyaan siapa yang harus memulai proses memaafkan ditemukan jawabannya.

\section{Memaafkan: Tindakan Kebaikan Bagi Orang Lain dan Bagi Diri Sendiri}

Kata memaafkan (Latin: perdonare) mempunyai hubungan dengan kata Latin: dare (yang berarti memberi) dan kata donare (yang artinya menghadiahkan). Dalam kata per-donare (memaafkan), ada preposisi "per" yang dalam bahasa Latin merujuk pada ide tentang suatu kesempurnaan, suatu kepenuhan. Karena itu memaafkan (per-donare) sesungguhnya berarti memberi atau menghadiahkan secara penuh, utuh, total. Memberi secara sempurna. Suatu tindakan kebaikan yang paling tinggi yang kita lakukan kepada orang lain, tetapi juga kepada diri kita sendiri (S. Nicolli, Enrica e M. Tortalla, 2008: 75).

Dalam arti ini, tindakan memaafkan itu bukan saja suatu tindakan kebaikan yang paling tinggi yang kita alamatkan kepada dia yang telah menghina atau mengkhianati diri kita, tetapi juga pada saat yang sama sebenarnya kita sedang melakukan suatu kebajikan yang paling tinggi nilainya terhadap diri kita sendiri. 
Dengan demikian, tindakan memaafkan sesungguhnya adalah jalan paling benar untuk menemukan kembali ketenangan dan kedamaian di dalam bathin, karena hal yang mendatangkan beban dan kerugian bagi diri dan orang lain telah dilepaskan (S. Nicolli, Enrica e M. Tortalla, 2008: 76).

Dalam bingkai pemahaman ini, tindakan memaafkan atau memberi maaf itu serentak membawa pembebasan bagi penghina (dia yang menyebabkan orang sakit dan terluka) serta dia yang menjadi korban penghinaan. Di sini, memaafkan menjadi suatu tindakan kasih. Mengapa? Karena tindakan itu bukan saja mendatangkan sukacita bagi dia yang mengalami perbuatan kasih, melainkan juga dia yang telah menunjukkan kasih itu. Memaafkan adalah tindakan kasih, karena melalui tindakan memberi maaf, orang sesungguhnya sedang memperlihatkan kebajikannya dalam relasinya dengan yang lain. Dengan kata lain, tindakan memaafkan adalah suatu kebajikan yang murni, suatu kebaikan yang benar.

Pemberian maaf sebagai tindakan kebajikan paling tinggi hanya dapat ditemukan dalam tindakan maafmemaafkan. Karena itu, setiap kesalahan atau tindakan yang mendatangkan kerugian dan petaka bagi orang lain harus segera dipulihkan (diselesaikan, dibereskan). Kalau tidak dilakukan, maka hal itu akan sangat mengganggu relasi antara penghina (l'offensore) dan si dia yang terluka (l'offeso).

\section{Memaafkan: Tindakan Yang Merujuk ke Masa Lampau}

Tindakan memaafkan atau memberi maaf umumya lahir dari seorang pribadi yang terluka. Tetapi tindakan memaafkan itu sendiri tergantung dari penghinaan yang dilakukan oleh penghina. Ingatan atau kenangan (memoria) mengingatkan kita akan pengalaman-pengalaman yang telah kita lakukan pada masa lampau. Dengan itu, memoria sesungguhnya adalah pengalaman dan pengetahuan masa lampau yang tersimpan. Pemahaman ini menunjukkan kepada kita bahwa memoria adalah suatu hal yang merujuk ke masa lampau. Secara khusus pengalaman-pengalaman. Memoria ibarat pemanggilan kembali atau pengingatan kembali akan ingatan melalui suatu tindakan kesadaran yang aktual. Karena itu, ketika berbicara tentang memoria, perhatian rujukannya secara langsung terarah kepada perwujudan kapasitas manusiawi dengan menghadirkan kembali gambaran-gambaran yang didapat pada masa lampau (Enciclopedia Filosofica III Li-Rei, 1957: 486 dan 494).

Setiap tindakan memaafkan adalah suatu tindakan yang menciptakan kembali ingatan atau kenangan, kenangan akan pengalaman yang terjadi pada masa lalu. Tindakan memaafkan itu memerlukan segera memoria (kenangan) akan tindakan penghinaan dengan cukup jelas. Hal ini dimaksudkan agar si korban (terluka) dapat menawarkan suatu maaf yang tidak meninggalkan bayang-bayang dengan motif dendam (Jean Laffitte, 2000: 67).

Tetapi memaafkan dengan tanpa meninggalkan bayang-bayang dengan motif dendam, bukanlah hal yang mudah. Kalau mau sampai pada sebuah maaf yang otentik, maka ia memerlukan latihan diri yang sungguh. Karena itu Littré mendefinisikan memoria sebagai "menghadirkan kembali ke dalam pikiran, ide-ide dan konsep-konsep objektif yang pada gilirannya dapat menghasilkan perasaan-perasaan di dalam diri" (Jean Laffitte, 2000: 67). Lalande menambahkan bahwa memoria adalah suatu perubahan yang berangsur-angsur di dalam pikiran dasar kita, yaitu pengakuan dari setiap kita akan masa lampau, karena masa lampau itu berbicara tentang suatu fungsi psikis yang penting dalam melahirkan kesadaran di dalam diri dengan karakteristik tertentu (Jean Laffitte, 2000: 67). Dengan pemahaman ini, dapatlah ditegaskan bahwa memoria adalah suatu proses menghadirkan kembali (memanggil kembali) semua pengalaman masa lampau melalui ingatan. Dan tindakan memaafkan adalah tindakan yang berjalan melalui proses menghadirkan kembali pengetahuan dan pengalaman masa lampau itu.

\section{Memaafkan: Bukanlah Perkara Yang Gampang}


Untuk memahami bahwa tindakan memaafkan bukanlah perkara yang gampang, kita menyebut dua tipe memoria, yaitu memoria aktif dan memoria pasif. Memoria aktif adalah kenangan atau ingatan yang senantiasa memanggil kembali penghina dan korban untuk berjalan menuju masa lampau, untuk melihat dan mengingat kembali tindakan penghinaan yang telah dilakukan. Sedangkan memoria pasif umumnya muncul dalam diri dia yang dihinakan. Ketika dia melihat atau memandang wajah pelaku yang menghinanya, langsung muncul penolakan dalam dirinya, dia tidak ingin memaafkannya. Korban tidak mau memaafkan, karena korban masih menyimpan kenangan pahit masa lalu. Ini adalah sebuah rintangan, persoalan dalam hal memberi maaf, terutama untuk penghinaan-penghinaan yang berat. Dalam kasus ini, seandainya pada akhirnya korban sampai melakukan tindakan memaafkan, pemberian maafnya itu bukanlah pemberian maaf yang tulus. Mengapa? Karena hatinya sebenarnya belum sungguh terobati. Hatinya yang sakit karena tindakan penghinaan yang dilakukan terhadapnya itu belum disembuhkan. Sampai pada titik ini, bisa dikatakan bahwa tindakan memaafkan atau memberi maaf itu sesungguhnya bukanlah perkara yang mudah. Tindakan memaafkan yang ingin dilakukan oleh dia yang dihinakan atau dikhianati, bagaimanapun, acapkali mengingatkan dia akan pengalaman rasa sakitnya di masa lampau (Jean Laffitte, 2000: 68).

Ketika tindakan penghinaan pada masa lampau diingat lagi, kenangan itu tidak saja melahirkan penderitaan (rasa sakit) pada diri korban, tetapi juga pada diri pelaku (penghina). Di samping itu, Kenangan akan tindakan penghinaan itu juga membuat pelaku sadar akan kesalahannya. Dalam hubungan dengan penderitaan (rasa sakit), pelaku adalah penyebab penderitaan. Dia adalah penyebab penderitaan karena dialah yang melakukan kesalahan. Tetapi, bagaimanapun penderitaan yang dialami oleh pelaku, tidak sama dengan yang dirasakan oleh korban. Penderitaan (rasa sakit) yang tidak pernah dilupakan adalah penderitaan yang dialami oleh korban. Untuk menegaskan hal ini, Viktor Hugo mengatakan: "orang yang dilukai hatinya memiliki ingatan lebih baik dari pada orang yang melakukannya. Pelaku bisa saja lupa akan tindakan penghinaan atau pengkhianatan yang ia lakukan, tetapi bagi korban, pengkhianatan itu selalu datang menghantuinya di dalam hatinya (Jean Laffitte, 2000: 68)".

Sampai di sini diketahui bahwa memoria yang menghambat tindakan memberi maaf adalah memoria pasif. Karena walaupun secara pasif, tindakan penghinaan itu tidak diingat lagi oleh pelaku, namun tidak demikian oleh korban. Dalam arti ini, tindakan penghinaan atau pengkhianatan di satu pihak bisa saja telah menjadi memoria pasif bagi pelaku; tetapi di pihak lain masih tetap sebagai memoria aktif bagi korban. Pelaku bisa saja lupa akan apa yang dia lakukan terhadap korban, tetapi korban selalu ingat akan penghinaan yang telah dilakukan terhadap dirinya. Dan ingatan yang selalu disertai dengan rasa sakit inilah yang memberatkan si korban untuk memberi maaf. Dia tidak memaafkan karena dia masih menyimpan kenangan pahit masa lalu.

\section{Penutup}

Memaafkan berarti memberi secara utuh, menyerahkan secara penuh, menghadiahkan secara total. Memaafkan dengan demikian berarti memberi secara sempurna kepada orang lain. Sebagai pemberian yang utuh, total dan sempurna yang diberikan kepada orang lain, pemberian maaf bukan saja melahirkan pembebasan bagi pelaku penghinaan, melainkan juga bagi si korban. Tindakan memaafkan mendatangkan rasa tenang, senang dan damai, baik bagi pelaku maupun korban. Karena itu, memaafkan menjadi suatu tindakan kebaikan yang paling tinggi yang orang lakukan terhadap orang lain, tetapi juga terhadap dirinya sendiri. Melalui tindakan memaafkan itu, relasi yang putus antara pelaku dan korban menjadi terjalin kembali.

Kendati tindakan memaafkan dapat mendatangkan rasa damai dalam diri pelaku dan korban sekaligus, dalam kenyataannya, memberi maaf bukanlah hal yang mudah. Mengapa? Karena tindakan memaafkan selalu memanggil orang (pelaku maupun korban) untuk berjalan ke masa lampau hidupnya. Berjalan menuju masa 
lampau berarti menghadirkan kembali kenangan dan pengalaman masa lampau. Kenangan akan pengalaman masa lampau inilah yang sering menjadi rintangan dalam proses memaafkan. Mengapa? Karena dalam hal ini, pelaku bisa saja lupa akan penghinaan yang dia lakukan, tetapi tidak demikian bagi si korban. Bagi korban, mengingat masa lalu sama dengan membangkitkan lagi luka lama. Dan itu melahirkan rasa sakit di dalam hati. Dalam situasi macam ini memberi maaf menjadi perkara yang tidak mudah.

\section{Kepustakaan}

Enciclopedia Filosofica III Li-Rei, Venezia-Roma, Istituto Per La Collaborazione Culturale, 1957

Jean Laffitte, Il Perdono Transfigurato, Bologna, Edizioni Dehoniane, 2000

J. L. Brugues, Dizionario Di Morale Cattolica, Bologna, Edizioni Studio Domenicano, 1994

Lorenzo Lini, Dizionario Italiano-Indonesiano, Bologna, Editrice Missionaria Italiana,1982

N. Zingarelli, Lo Zingarelli. Vocabulario Della Lingua Italiana, Bologna, Zanichelli, 2004

S. Nicolli, Enrica e M. Tortalla, Il Perdono In Famiglia, Siena, Cantagalli, 2008 